\title{
PENGARUH FINANCIAL DISTRESS, GROWTH OPPORTUNITIES DAN LIQUIDITY TERHADAP KEPUTUSAN HEDGING PADA PERUSAHAAN PERTAMBANGAN BEI
}

\section{Luh Galang Marhaenis ${ }^{1}$ Luh Gede Sri Artini}

\author{
${ }^{1,2}$ Fakultas Ekonomi dan Bisnis Universitas Udayana, Bali, Indonesia \\ email: glngmrhns@yahoo.com
}

\begin{abstract}
ABSTRAK
Upaya yang dapat dilakukan untuk mengurangi dampak dari adanya risiko usaha yaitu dengan menerapkan kebijakan hedging sehingga mengurangi dampak yang ditimbulkan dari fluktuasi kurs valuta asing serta melindungi aset perusahaan dari eksposur risiko tersebut yaitu pada perusahaan pertambangan. Tujuan penelitian ini adalah untuk menjelaskan pengaruh financial distress, growth opportunities dan liquidity terhadap keputusan hedging pada perusahaan pertambangan. Teknik sampling pada penelitian ini menggunakan purposive sampling karena dalam penelitian ini didapatkan sampel sebanyak 32 perusahaan dari 48 populasi perusahaan pertambangan. Teknik analisis data yang digunakan dalam penelitian ini menggunakan regresi logistik. Hasil analisis data menunjukkan bahwa financial distress berpengaruh negatif dan tidak signifikan terhadap keputusan hedging. Growth opportunities berpengaruh positif dan signifikan terhadap keputusan hedging. Liquidity berpengaruh negatif dan signifikan terhadap keputusan hedging.

Kata Kunci: financial distress, growth opportunities, hedging, liquidity
\end{abstract}

\begin{abstract}
Efforts can be made to reduce the impact of business risks by implementing a hedging policy so as to reduce the impact caused by fluctuations in foreign exchange rates and protect the company's assets from risk exposure, namely mining companies. The purpose of this study is to explain the effect of financial distress, growth opportunities and liquidity on hedging decisions in mining companies. The sampling technique in this study used purposive sampling because in this study a sample of 32 companies from 48 populations of mining companies was obtained. Data analysis techniques used in this study used logistic regression. The results of data analysis show that financial distress has a negative and not significant effect on hedging decisions. Growth opportunities have a positive and significant effect on hedging decisions. Liquidity has a negative and significant effect on hedging decisions.

Keywords: financial distress, growth opportunities, hedging, liquidity
\end{abstract}




\section{PENDAHULUAN}

Perkembangan ekonomi internasional yang semakin pesat ditandai dengan adanya arus perdagangan baik modal maupun barang antar negara (Ariani, 2017). Perusahaan multinasional di berbagai negara dalam menjalankan suatu bisnis tidak akan terlepas dari kegiatan perdagangan internasional. Perdagangan internasional merupakan suatu aktivitas transaksi jual beli yang dilakukan dengan pihak luar atau dengan antar negara (Dewi, 2018). Perdagangan internasional didukung oleh berbagai hal, seperti dorongan dalam memenuhi kebutuhan baik barang atau jasa, untuk memperoleh keuntungan dan dapat meningkatkan pendapatan dalam negara, dan juga adanya perbedaan pengetahuan atau kemampuan dalam teknologi untuk mengolah sumber daya yang ada (Sharagih dan Musdholifah, 2017).

Perdagangan internasional sangat mempengaruhi pertumbuhan dan perkembangan ekonomi suatu negara, karena saling bersaing di dalam pasar internasional (Rinaldi et al., 2017). Kegiatan perdagangan internasional semakin meningkat karena didorong oleh beberapa faktor seperti adanya perbedaan penguasaan ilmu pengetahuan dan teknologi dalam mengolah sumber daya ekonomi, saling memenuhi kebutuhan barang dan jasa dalam negeri, keinginan untuk memperoleh keuntungan dan memiliki kelebihan produk dalam negeri sehingga perlu pasar baru guna memasarkan produknya, serta terdapat keinginan untuk membuka kerja sama, hubungan politik dan dukungan dari negara lain (Irawan, 2014).

Perdagangan internasional dapat menyebabkan terjadinya peningkatan dalam persaingan serta fluktuasi harga pasar sehingga berakibat pada peningkatan risiko usaha yang harus ditanggung oleh perusahaan (Jiwandhana, 2016). Perdagangan internasional juga dapat menimbulkan dampak berupa hutang maupun piutang yang dapat menguntungkan bahkan merugikan perusahaan (Widyagoca, 2016). Masalah perusahaan yang telah melakukan transaksi internasional akan lebih rumit dibandingkan dengan perusahaan yang hanya mengandalkan transaksi domestik. Perusahaan yang melakukan perdagangan internasional juga berpotensi terkena risiko yang berupa risiko tingkat suku bunga, valuta asing serta harga komoditas yang berdampak negatif terhadap arus kas dan nilai perusahaan yang dapat mengancam kelangsungan hidup perusahaan (Situmeang, 2018).

Risiko terbesar dari transaksi internasional adalah risiko fluktuasi kurs valuta asing (Krisdian, 2017). Risiko fluktuasi kurs valuta asing yang tidak dapat diantisipasi oleh perusahaan dapat berdampak pada penjualan, harga, laba eksportir dan importir. Risiko fultuasi kurs valuta asing yang dialami oleh perusahaan multinasional disebabkan karena adanya aktivitas dari perdagangan yang tidak terlepas dari penggunaan valuta asing dalam melakukan transaksi ekspor maupun impor sehingga perusahaan memiliki eksposur valuta asing (Sharagih dan Musdholifah, 2017). Eksposur valuta asing merupakan risiko yang akan dihadapi oleh setiap perusahaan yang melakukan transaksi internasional, baik impor maupun ekspor.

Kurs valuta asing selalu mengalami fluktuasi setiap tahunnya dapat dilihat pada Gambar 1. 


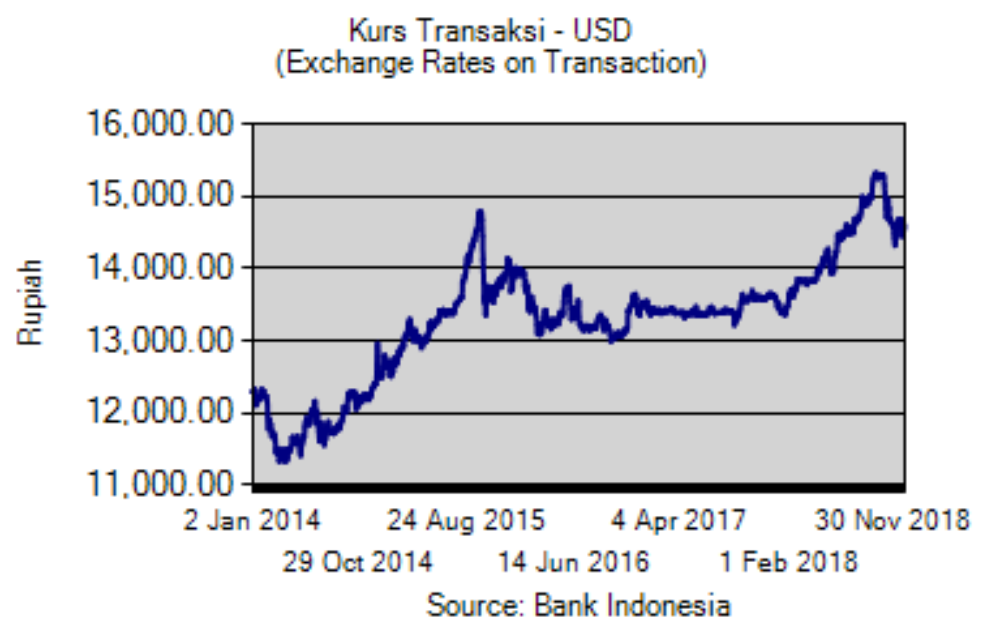

\section{Gambar 1. \\ Kurs Valuta Asing Dolar Amerika}

Sumber: www.bi.go.id, 2019

Gambar 1. menggambarkan terjadinya fluktuasi kurs dolar amerika dari tahun 2014 hingga tahun 2018. Gambar grafik kurs transaksi USD tersebut menunjukkan bahwa kurs transaksi USD terhadap IDR selama 5 tahun terakhir yaitu mulai tanggal 2 Januari 2014 hingga 30 November 2018. Data tersebut dapat diartikan bahwa ketika perusahaan akan melakukan transaksi valuta asing baik itu ekspor maupun impor akan mengalami risiko terhadap eksposur valuta asing. Gambar grafik kurs tersebut menunjukkan bahwa terdapat fluktuasi nilai tukar USD terhadap IDR pertahunnya yang dimulai pada tahun 2014 hingga 2018. Harga impor barang akan lebih mahal sehingga berdampak pada peningkatan harga barang pada saat IDR terdepresiasi atau ketika mata uang USD terapresiasi. Kondisi tersebut dapat menyebabkan kerugian pada perusahaan yang melakukan transaksi internasional dengan perbedaan mata uang asing, pada saat mata uang domestik atau IDR mengalami depresiasi tentu perusahaan tersebut harus mengeluarkan lebih banyak uang lagi untuk membeli suatu produk pada transaksi tersebut.

Dampak langsung yang timbul akibat fluktuasi kurs valuta asing yaitu turunnya omzet penjualan, penetapan harga produk yang tinggi dan tingkat laba yang kian menurun (Jiwandhana, 2016). Dampak tersebut dapat dilihat dari turunnya laba perusahaan, laba per lembar saham dan juga harga saham di pasar modal (Krisdian, 2017). Fluktuasi kurs valuta asing yang dapat menimbulkan risiko yang akan ditanggung perusahaan, maka dari itu perusahaan dapat melakukan manajemen risiko untuk mengurangi kemungkinan risiko yang dihadapi oleh perusahaan.

Risiko fluktuasi kurs valuta asing dalam perdagangan internasional yang dilakukan oleh perusahaan perlu dikelola agar tidak terjadi kerugian yang besar bagi perusahaan (Krisdian, 2017). Manajemen risiko diperlukan oleh perusahaan untuk mengelola atau mengoptimalkan risiko yang akan dihadapi perusahaan dalam 
melakukan transaksi internasional. Perusahaan yang melakukan perdagangan internasional diharapkan melakukan manajemen risiko kurs valuta asing dengan menggunakan instrumen derivatif (Dewi, 2016).

Instrumen derivatif dapat didefinisikan sebagai kontrak perjanjian antara dua pihak untuk menjual dan membeli sejumlah barang (baik komoditas maupun sekuritas) pada tanggal tertentu di masa yang akan datang dengan harga yang telah disepakati pada saat ini. Contoh dari instrumen derivatif adalah option, forward, futures, dan swap. Instrumen derivatif diharapkan mampu mengurangi risiko yang akan dihadapi oleh perusahaan multinasional dalam melakukan perdagangan internasional. Suatu perusahaan dapat mengetahui risiko yang akan dihadapi dengan mengidentifikasi terlebih dahulu eksposur apa yang akan dihadapi (Raghavendra dan Velmurugan, 2014).

Penggunaan instrumen derivatif dapat bermanfaat untuk mengunci hargaharga suatu aset atau produk sehingga perusahaan dapat terhindar dari risiko perubahan nilai aset tersebut pada masa yang akan datang, kegiatan mengunci harga ini dapat pula dikatakan dengan hedging (Ross et al., 2019). Hedging merupakan suatu strategi yang dilakukan untuk mengurangi risiko bisnis yang tidak terduga di samping tetap dimungkinkannya memperoleh keuntungan (Zeinora, 2016). Keputusan hedging diambil oleh manajemen perusahaan untuk menghindari atau mencurangi biaya risiko atas perubahan kurs yang tak terduga (Tuzcu, 2015). Pengambilan keputusan hedging selain untuk mengurangi risiko harga juga nantinya akan mempengaruhi nilai perusahaan tersebut (Chaudry, 2014). Pengambilan keputusan hedging akan hilang ketika jenis risiko mudah diidentifikasi oleh investor individu (Altuntas et al., 2017).

Pada negara-negara maju saat ini, pengambilan keputusan hedging dengan menggunakan instrumen derivatif mengalami peningkatan dalam beberapa tahun terakhir, penelitian empiris menemukan bahwa $60 \%$ perusahaan di Inggris telah menggunakan instrumen derivatif dalam pengambilan keputusan hedging dan di Brazil sebanyak $54 \%$ perusahaan yang telah memanfaatkan instrumen derivatif (Saraswati, 2019). Studi empiris pertama di Indonesia menemukan bahwa hanya sekitar 28,8\% perusahaan yang menggunakan instrumen derivatif dalam pengambilan keputusan hedging di Indonesia (Candradewi, 2018).

Pengambilan keputusan hedging pada perusahaan di Indonesia dapat dijelaskan menggunakan teori mengenai motivasi pengambilan keputusan hedging di suatu perusahaan. Teori motivasi tersebut didasarkan pada dua aspek yaitu mengenai maksimisasi nilai pemegang saham (shareholder value maximization) dan maksimisasi kepuasan manajer (manager utility maximization). Penelitian mengenai hedging memfokuskan pada teori motivasi shareholder value maximization, karena pada teori ini memfokuskan pada hipotesis yang membahas mengenai pengurangan biaya - biaya transaksi yang berkaitan dengan financial distress, leverage, liquidity, profitabilitas (Megawati, 2016). Biaya transaksi merupakan biaya yang rentan terhadap fluktuasi valuta asing sebagai akibat dari adanya aktivitas transaksi multinasional yang dilakukan oleh perusahaan (Jiwandhana, 2016).

Financial distress merupakan suatu tahap penurunan pada kondisi keuangan perusahaan sebelum perusahaan mengalami kebangkrutan ataupun likuidasi. 
Indikasi kebangkrutan suatu perusahaan dapat dilihat melalui financial distress, sehingga mendorong pihak manajemen untuk mengambil keputusan hedging guna melindungi perusahaan dari risiko yang dihadapi ketika melakukan transaksi internasional (Aslikan dan Rokhmi, 2017). Keputusan hedging dianggap mampu mengurangi risiko financial distress yang akan dihadapi oleh perusahaan ketika akan membeli atau menjual suatu produk dengan menggunakan nilai valuta asing sehingga perusahaan tidak akan dirugikan dimasa yang akan datang akibat terjadinya fluktuasi kurs valuta asing.

Penelitian yang dilakukan oleh Arnold et al. (2014) menunjukkan bahwa financial distress berpengaruh positif terhadap aktivitas hedging. Penelitian yang dilakukan oleh Krisdian dan Badjra (2017) menunjukkan bahwa financial distress memiliki pengaruh yang positif dan signifikan terhadap keputusan hedging yang diproksikan melalui z-score. Penelitian tersebut juga didukung oleh hasil dari penilitian Aslikan dan Rokhmi (2017) yang juga menunjukkan hasil positif antara financial distress terhadap keputusan hedging. Perusahaan yang mengalami kesulitan keuangan akan berhati-hati dalam mengelola keuangannya sehingga akan melakukan hedging untuk mengurangi risiko terhadap transaksi valuta asing. Penelitian tersebut berbanding terbalik dengan hasil penelitian dengan hasil penelitian Guniarti (2014) menunjukkan hasil financial distress berpengaruh negatif terhadap keputusan hedging. Pada penelitian Sianturi (2015) juga menemukan bahwa terdapat pengaruh negatif antara financial distress terhadap keputusan hedging. Penelitian dari Fatimia dan Sulhan (2016) juga memberikan hasil bahwa financial distress berpengaruh negatif terhadap kebijakan hedging.

Peluang Pertumbuhan (Growth Opportunities) adalah suatu ukuran peluang perusahaan dalam mengembangkan usahanya di masa depan. Perusahan dengan tingkat pertumbuhan yang tinggi lebih banyak membutuhkan dana di masa depan, terutama dana eksternal untuk memenuhi kebutuhan investasinya atau untuk memenuhi kebutuhan untuk membiayai pertumbuhannya. Perusahan yang berpeluang untuk mencapai pertumbuhan yang tinggi pasti akan mendorong perusahan untuk terus melakukan ekspansi usaha dan dana yang dibutuhkan pasti tidaklah sedikit dan kemungkinan dana internal yang dimiliki jumlahnya terbatas sehinga akan mempengaruhi keputusan struktur modal atau pendanan suatu perusahaan.

Semakin tinggi tingkat pertumbuhan suatu perusahaan, maka semakin perlu melakukan kegiatan hedging dalam perusahaan untuk melindungi risiko yang dapat menimbulkan kerugian bagi perusahaan tersebut. Penelitian yang dilakukan Nuzul dan Lautania (2015) juga menyatakan hasil yang sama bahwa Growth Opportunities berpengaruh positif terhadap pengambilan keputusan hedging. Penelitian tersebut sejalan dengan penelitian yang dilakukan oleh Mehmood (2014) serta Medina (2016) yang menyatakan bahwa Growth Opportunities berpengaruh positif terhadap keputusan hedging. Hasil penelitian tersebut bertentangan dengan hasil penelitian Widyagoca (2016) dan Guniarti (2014) yang menyatakan bahwa Growth Opportunities berpengaruh negatif terhadap pengambilan keputusan hedging.

Liquidity merupakan kemampuan perusahaan untuk menyelesaikan kewajiban jangka pendeknya kepada kreditor jangka pendek. Tingkat liquidity 
sangatlah penting bagi suatu perusahaan untuk dapat memenuhi kewajibannya tepat pada waktunya, namun apabila perusahaan memiliki tingkat liquidity yang sangat tinggi artinya perusahaan tersebut memiliki aset tertanam yang sangat besar.

Semakin tinggi nilai liquidity suatu perusahaan, maka hedging yang dilakukan akan rendah karena risiko keuangan rendah. Liquidity berpengaruh negatif terhadap pengambilan keputusan hedging sesuai dengan penelitian (Dewi dan Purnawati (2016), Irawan (2014) dan Mehmood (2014) yang juga menyatakan liquidity dengan keputusan hedging berpengaruh negatif. Hasil penelitian tersebut berbanding terbalik dengan penelitian Medina (2016), Fatimia (2016) yang menyatakan bahwa liquidity berpengaruh positif terhadap keputusan hedging.

Penelitian ini menggunakan perusahaan dalam sektor pertambangan yang terdaftar di Bursa Efek Indonesia karena perusahaan dalam sektor pertambangan merupakan salah satu sektor perusahaan yang aktif dalam melakukan ekspor dan impor. Pertumbuhan ekspor perusahaan yang semakin tinggi menyebabkan perusahaan tersebut cenderung terkena risiko lebih banyak sehingga kemungkinan kerugian yang ditanggung oleh perusahaan lebih besar dibandingkan dengan perusahaan yang tidak melakukan perdagangan internasional. Perusahaan yang aktif dalam melakukan ekspor dan impor cenderung memiliki eksposur valuta asing yang lebih besar, sehingga untuk melindungi produk serta aset dari fluktuasi valuta asing maka perusahaan cenderung akan melakukan hedging.

Trend grafik aktivitas hedging yang dilakukan oleh perusahaan sektor pertambangan meningkat setiap tahunnya dapat dilihat pada Gambar 2.

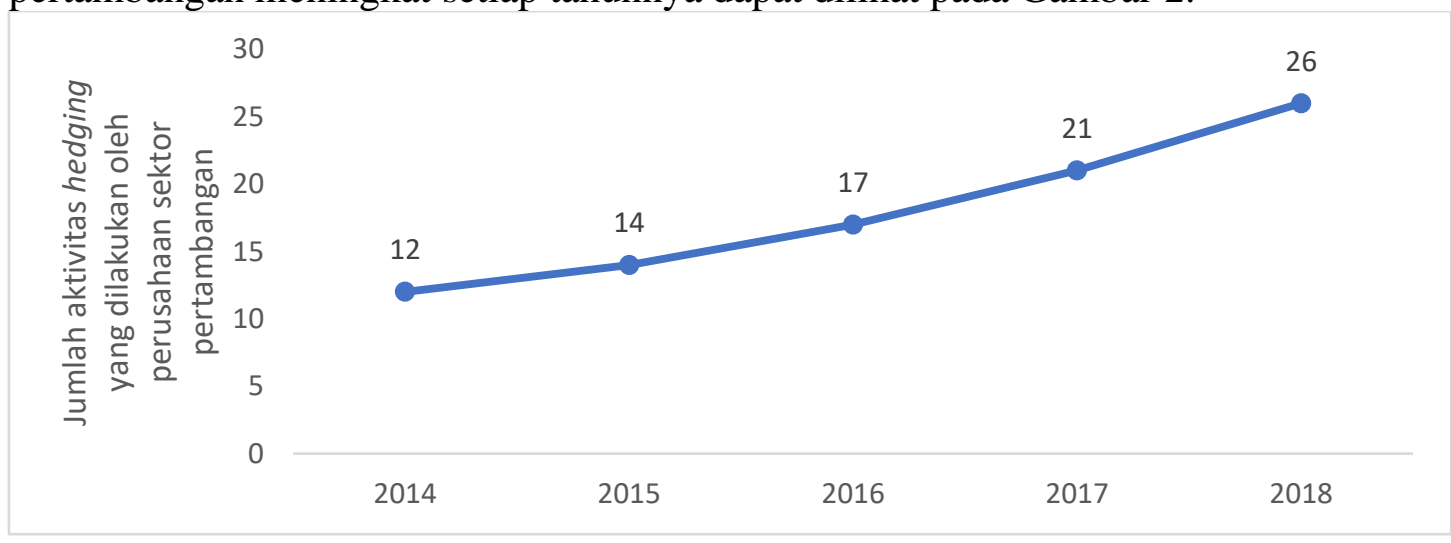

\section{Gambar 2. Trend Grafik Aktivitas Hedging yang dilakukan Oleh Perusahaan Sektor Pertambangan dari Tahun 2014-2018}

Berdasarkan trend grafik tersebut, perusahaan dalam sektor pertambangan yang melakukan kebijakan hedging meningkat di setiap tahunnya. Tahun 2014 hingga 2018 terdapat banyak perusahaan dalam sektor pertambangan yang mengalami defisit pada kas perusahaannya yang diakibatkan karena fluktuasi arus kas akibat dari perdagangan internasional. Industri pertambangan mengalami penurunan ditengah meingkatnya perekonomian nasional. Data dari Badan Pusat Statistika (BPS) menyatakan bahwa sektor pertambangan dan penggalian mengalami kontraksi negatif 0,49\%, padahal pertumbuhan ekonomi kuartal I 2017 tembus 5,01\%, membaik jika dibanding dengan periode yang sama tahun lalu, yaitu 
4,92\%. Hal ini dikarenakan adanya penurunan produksi tembaga dan emas oleh PT Freeport Indonesia dan PT Amman sehingga pada tahun 2014 terdapat 12 perusahaan yang melakukan hedging kemudian meningkat setiap tahunnya hingga pada tahun 2018 terdapat 26 perusahaan yang menggunakan kebijakan hedging untuk melindungi perusahaan dari eksposur valuta asing yang dihadapi oleh perusahaan.

Financial distress merupakan suatu kondisi dimana keuangan perusahaan dalam keadaan tidak sehat atau sedang krisis (Platt, 2014). Kesulitan keuangan perusahaan dapat dikurangi dengan melakukan aktivitas hedging. Salah satu penyebab kesulitan keuangan adalah adanya serangkaian kesalahan, pengambilan keputusan yang tidak tepat, dan kelemahan-kelemahan yang saling berhubungan yang dapat menyumbang secara langsung maupun tidak langsung kepada manajemen serta tidak adanya atau kurangnya upaya mengawasi kondisi keuangan sehingga penggunaan uang tidak sesuai dengan keperluan (Brigham et al., 2018; 78).

Melindungi arus kas perusahaan dengan instrumen derivatif dapat menghindarkan perusahaan dari risiko financial distress dan financial distress merupakan salah satu penentu dalam strategi keputusan hedging (Chong et al., 2014). Penelitian tersebut juga didukung oleh hasil dari Wulandari (2018), Nuzul dan Lautania (2015) dan Yustika (2015) yang menemukan hasil bahwa financial distress yang diukur dengan menggunakan z-score berpengaruh negatif dan tidak signifikan terhadap keputusan hedging. Perusahaan yang mengalami kesulitan keuangan akan berhati-hati dalam mengelola keuangannya sehingga akan melakukan hedging untuk mengurangi risiko terhadap transaksi valuta asing.

Semakin rendah nilai z-score suatu perusahaan maka tingkat pengambilan keputusan hedging akan semakin tinggi. Perusahaan dalam keadaan yang kurang sehat atau cenderung mengalami kebangkrutan maka perusahaan akan mencoba melindungi aset perusahaan agar tidak terjadi kesulitan keuangan di kemudian hari dengan melakukan aktivitas hedging.

$\mathrm{H}_{1}$ : Financial distress berpengaruh negatif dan tidak signifikan terhadap keputusan hedging

Growth opportunities merupakan suatu ukuran peluang perusahaan dalam mengembangkan usahanya di masa depan. Perusahaan yang memiliki pertumbuhan yang tinggi lebih memilih hutang sebagai sumber pendanaan yang besar dibandingkan dengan perusahaan yang pertumbuhannya lambat (Weston dan Brigham, 2018: 90).

Penelitian yang dilakukan Sianturi (2015) studi kasus pada perusahaan non finansial yang terdaftar di Bursa Efek Indonesia periode 2010-2014 dengan menggunakan metode regresi logistic menemukan hasil bahwa growth opportunities berpengaruh positif dan signifikan terhadap keputusan penggunaan hedging dengan instrumen derivatif. Penelitian yang dilakukan (Nuzul dan Lautania (2015) juga menyatakan hasil yang sama bahwa Growth Opportunities berpengaruh positif terhadap pengambilan keputusan hedging. Penelitian tersebut sejalan dengan penelitian yang dilakukan oleh Mehmood (2014) serta Medina (2016) yang menyatakan bahwa Growth Opportunities berpengaruh positif terhadap keputusan hedging. 
Growth opportunities dapat menunjukkan peluang suatu perusahaan, semakin tinggi growth opportunities menunjukkan peluang perusahaan untuk maju juga tinggi, sehingga untuk mengambil kesempatan tersebut diperlukan dana dengan jumlah yang besar dalam membiayai pertumbuhan perusahaan tersebut. Keputusan hedging sangat baik dilakukan pada saat perusahaan menunjukkan peluang untuk tumbuh karena perusahaan juga harus melindungi aset yang sudah dimiliki sebelumnya.

$\mathrm{H}_{2}$ : Growth opportunities berpengaruh positif signifikan terhadap keputusan hedging

Sartono (2014: 29) mengemukakan bahwa liquidity perusahaan menunjukkan kemampuan perusahaan untuk membayar kewajiban finansial jangka pendek tepat pada waktunya. Risiko liquidity terjadi jika perusahaan mengalami kesulitan membayar kewajiban jangka pendek.

Penelitian Dewi dan Purnawati (2016) menemukan hasil bahwa liquidity berpengaruh negatif dengan penerapan hedging. Mehmood (2014) melakukan penelitian mengenai kebijakan hedging dengan derivatif valuta asing, hasil penelitian diperoleh bahwa probabilitas perusahaan menerapkan kebijakan hedging secara negatif dan tidak signifikan berpengaruh dengan current ratio. Penelitian (Aslikan dan Rokhmi (2017) juga menemukan hasil bahwa liquidity berpengaruh negatif dan signifikan terhadap keputusan hedging.

Pengaruh liquidity dengan pengambilan keputusan hedging berpengaruh negatif dan signifikan. Semakin tinggi nilai liquidity maka semakin rendah keputusan hedging yang akan diambil karena risiko kesulitan keuangan yang muncul cenderung rendah.

$\mathrm{H}_{3:}$ Liquidity berpengaruh negatif signifikan terhadap keputusan hedging

\section{METODE PENELITIAN}

Penelitian ini dilakukan pada perusahaan sektor pertambangan yang terdaftar dalam Bursa Efek Indonesia periode 2014-2018 dengan mengambil data melalui situs resmi www.idx.co.id. Data yang didapatkan berbentuk laporan keuangan tahunan dan laporan historis lainnya. Obyek penelitian adalah keputusan hedging perusahaan sektor pertambangan yang terdaftar di Bursa Efek Indonesia pada periode tahun 2014-2018.

Hedging adalah kebijakan suatu perusahaan untuk melakukan penanggulangan dari risiko fluktuasi valuta asing yang dapat mengakibatkan perusahaan mengalami kerugian dengan menggunakan instrumen derivatif seperti future, forward, option, swap. Data kualitatif yang diperoleh dalam laporan keuangan tahunan perusahaan sektor pertambangan yang terdaftar di bursa efek Indonesia periode 2014-2018. Laporan keuangan tahunan perusahaan sektor pertambangan berisi data perusahaan ketika menggunakan instrumen derivatif dalam mengambil keputusan hedging. Laporan tersebut akan dinyatakan dalam variabel dummy, apabila perusahaan menggunakan instrumen derivatif sebagai aktivitas hedging maka akan diberi nilai 1 yang menandakan bahwa perusahaan tersebut melakukan aktivitas hedging, dan diberi angka 0 apabila perusahaan tidak melakukan aktivitas hedging. 
Pengukuran kesulitan keuangan dapat diterangkan dari perhitungan Altman z-score yang dikemukakan oleh Edward I. Altman. Altman z-score pada perusahaan sektor pertambangan go public ditentukan dengan menggunakan rumus sebagai berikut:

$$
\mathrm{Z}=1,2(\mathrm{WCTA})+1,4(\text { RETA) }+3,3 \text { (EBITTA) + 0,6 (MVEBVL)+ } 1 \text { (STA)..(1) }
$$

WCTA = Working Capital to Total Asset (modal kerja/aset total)

RETA $\quad=$ Retained Earning to Total Asset (laba ditahan/aset total)

EBITTA = Earning Before Interest and Taxes to Total Asset (laba sebelum bunga dan pajak/aset total)

MVEBVL = Market Value of Equity to Total Liabilities (nilai pasar saham/hutang total)

STA $\quad=$ Sales to Total Asset (penjualan/aset total)

Rumus tersebut digunakan karena perusahaan yang diteliti merupakan perusahaan go public maka model yang digunakan merupakan model pasar, sehingga perusahaan yang mempunyai skor $Z>2,99$ diklasifikasikan sebagai perusahaan sehat, sedangkan perusahaan yang mempunyai skor $\mathrm{Z}<1,81$ diklasifikasikan sebagai perusahaan potensial bangkrut, dan skor 1,81 sampai 2,99 diklasifikasikan sebagai perusahaan pada grey area atau daerah kelabu (Hanafi, 2015: 60). Semakin tinggi nilai Altman z-score maka perusahaan sedang dalam kondisi yang sehat, begitu pula sebaliknya yaitu perusahaan yang memiliki nilai Altman z-score rendah mengindikasikan perusahaan tersebut tergolong tidak sehat, atau kecenderungan mengalami kebangkrutan tinggi.

Growth opportunities merupakan suatu ukuran peluang perusahaan dalam mengembangkan usahanya di masa yang akan datang. Growth opportunities pada laporan keuangan perusahaan dalam sektor pertambangan periode 2014-2018 dihitung dengan menggunakan perbandingan antara MVE (market value of equity) dengan BVE (book value of equity). MVE adalah hasil perkalian dari harga saham penutupan akhir tahun dengan jumlah saham yang beredar pada akhir tahun. BVE diperoleh dari selisih total asset perusahaan dengan total kewajiban. Maka dalam mengukur growth opportunities menggunakan formulasi sebagai berikut:

$$
\begin{aligned}
& \text { Growth Opportunities }=\frac{M V E}{B V E} . . . . \\
& \text { MVE }=\text { Market Value of Equity } \\
& \mathrm{BVE} \quad=\text { Book Value of Equity }
\end{aligned}
$$

Liquidity menunjukkan kemampuan membayar kewajiban jangka pendek dengan aset lancar yang dimiliki oleh perusahaan sektor pertambangan periode 2014-2018. Penelitian ini menggunakan current ratio sebagai proksi dari liquidity. Current ratio adalah perbandingan dari total hutang lancar (hutang jangka pendek) dibandingkan dengan aktiva lancar (kas/bank, piutang, surat berharga dan persediaan), nilai rasio yang disarankan adalah minimal $150 \%$, yang menandakan perusahaan mampu menutupi seluruh hutang jangka pendeknya dengan menggunakan aktiva lancar yang ada. Current ratio dihitung dengan menggunakan rumus yang dikutip dari Wiagustini (2014: 87), yaitu: 
Current Ratio $=\frac{\text { Aktiva Lancar }}{\text { Pasiva Lancar }} \times 100 \%$

Populasi dalam penelitian ini adalah 48 Perusahaan sektor pertambangan di Bursa Efek Indonesia periode 2014 - 2018. Pemilihan sampel pada penelitian ini didasarkan pada perusahaan sektor pertambangan yang memenuhi beberapa kriteria - kriteria dengan metode purposive sampling. Teknik purposive sampling merupakan teknik penentuan sampel dengan pertimbangan atau kriteria tertentu. Kriteria tersebut yaitu perusahaan tersebut merupakan perusahaan sektor pertambangan di Bursa Efek Indonesia (BEI) dan secara fundamental memiliki eksposur valuta asing dan memiliki anak perusahaan di luar negeri.

Alasan menggunakan teknik purposive sampling karena dalam penelitian ini meneliti aktivitas hedging perusahaan yang memiliki eksposur valuta asing, sehingga perusahaan sektor pertambangan yang tidak memiliki eksposur valuta asing dan tidak melakukan transaksi luar negeri tidak termasuk ke dalam sampel pada penelitian ini.

Data yang diperoleh dari website Bursa Efek Indonesia didapatkan jumlah populasi sebanyak 48 perusahaan sektor pertambangan dan setelah dilakukan seleksi sampel dengan kriteria yang telah disebutkan di atas maka diperoleh sampel sebanyak 32 perusahaan sektor pertambangan yang memenuhi kriteria dan 16 perusahaan sektor pertambangan yang tidak memenuhi kriteria.

Penggunaan teknik analisis data regresi logistik dalam penelitian ini karena regresi logistik dapat menyelesaikan permasalahan dalam penelitian variabel terikat yang bersifat kategorik (Megawati, 2016). Regresi logistik digunakan karena memiliki beberapa kelebihan yaitu yang pertama regresi logistik mengandalkan ketelitian pertemuan asumsi normalitas multivariate dan kesamaan varian kovarian matrik semua kelompok, kedua yaitu banyak peneliti lebih menyukai logit analisis sama dengan regresi dengan uji straight forward dan metode regresi logistik memiliki kemampuan untuk menggabungkan pengaruh non-linier, ketiga yaitu regresi logistik sama dengan diskriminan analisis namun lebih tepat digunakan dalam kondisi tertentu seperti data tidak normal, terdapat multikolinearitas antar variabel bebas dan pelanggaran asumsi klasik lainnya. Adapun model umum regresi logistik yaitu sebagai berikut:

$$
\operatorname{Ln} \frac{\mathrm{P}}{1-\mathrm{p}}=\alpha+\beta 1 \mathrm{X} 1+\beta 2 \mathrm{X} 2+\beta 3 \mathrm{X} 3+\mathrm{e} .
$$

Keterangan:

$$
\begin{array}{ll}
\operatorname{Ln}=\frac{p}{1-p} & =\text { Aktivitas hedging dengan menggunakan instrumen derivatif } \\
\operatorname{Ln}=\frac{p}{1-p} & =1 \text { (terdapat aktivitas hedging) } \\
\operatorname{Ln}=\frac{p}{1-p} & =0 \text { (tidak terdapat aktivitas hedging) } \\
\operatorname{Ln} & =\text { Variabel terikat } \\
\mathrm{P} & =\text { Probabilitas } \\
\alpha & =\text { Konstanta regresi } \\
\beta 1 & =\text { Koefisien regresi variabel X1 } \\
\beta 2 & =\text { Koefisien regresi variabel X2 }
\end{array}
$$




\section{HASIL DAN PEMBAHASAN}

Statistik deskriptif berhubungan dengan pengumpulan dan peringkat data yang menggambarkan karakteristik sampel yang digunakan dalam sebuah penelitian. Analisis ini digunakan untuk menjelaskan karakteristik sampel terutama mencakup mengenai nilai rata - rata (mean), nilai ekstrim yang mencakup nilai minimum dan nilai maksimum serta standar deviasi.

Tabel 1. menunjukkan bahwa nilai minimum dari z-score sebagai variabel pertama adalah sebesar -5,66 yang terdapat pada PT Borneo Lumbung Energi \& Metal Tbk tahun 2015 sedangkan nilai maksimum dari variabel z-score adalah sebesar 11,28 yang terdapat pada PT Golden Energy Mines Tbk tahun 2014. Rata - rata variabel z-score sebesar 1,9211 dan standar deviasi sebesar 2,54475.

Pada variabel kedua yaitu MBVE didapatkan nilai minimum sebesar -2,55 yang terdapat pada PT Energi Mega Persada Tbk tahum 2016 sedangkan nilai maksimum dari variabel MBVE sebesar 11,05 yang terdapat pada PT Bayan Resources Tbk tahun 2015. Rata - rata dari variabel MBVE sebesar 1,4197 dan standar deviasi dari variabel ini sebesar 1,73510.

Nilai minimum dari variabel current ratio adalah sebesar 5,24 yang terdapat pada PT. Tirta Mahakam Resouces Tbk tahun 2016 sedangkan nilai maksimum dari variabel current ratio adalah sebesar 691,36 yang terdapat pada PT. Harum Energy Tbk tahun 2015. Rata - rata variabel Current Ratio yaitu sebesar 174,0838 dengan standar deviasi sebesar 115,9017.

Sampel dengan variabel hedging (Y) dapat dilihat pada Tabel 2.

Tabel 1.

Statistik Deskriptif Variabel Bebas

\begin{tabular}{lrrrrr}
\hline & N & Minimum & Maximum & \multicolumn{1}{c}{ Mean } & \multicolumn{1}{c}{ Std. Deviation } \\
\hline Z-Score & 160 & -5.66 & 11.28 & 1.9211 & 2.54475 \\
MBVE & 160 & -2.55 & 11.05 & 1.4197 & 1.73510 \\
Current Ratio & 160 & 5.24 & 691.36 & 174.0838 & 115.90173 \\
Valid N (listwise) & 160 & & & & \\
\hline
\end{tabular}

Sumber: Data diolah, 2019

Tabel 2.

Frekuensi Variabel Terikat

\begin{tabular}{|c|c|c|c|c|c|}
\hline & & Frequency & Percent & Valid Percent & $\begin{array}{c}\text { Cumulative } \\
\text { Percent }\end{array}$ \\
\hline \multirow[t]{3}{*}{ Valid } & 0 & 70 & 43.8 & 43.8 & 43.8 \\
\hline & 1 & 90 & 56.3 & 56.3 & 100.0 \\
\hline & Total & 160 & 100.0 & 100.0 & \\
\hline
\end{tabular}

Sumber: Data diolah, 2019

Pada penelitian ini perusahaan pertambangan yang melakukan aktivitas hedging diberi kode 1 sedangkan perusahaan pertambangan yang tidak melakukan hedging diberi kode 0. Berdasarkan Tabel 2 dapat dilihat bahwa terdapat aktivitas hedging yang dilakukan oleh perusahaan pertambangan sebanyak 90 kali dan 
persentase sebesar 56,3\%, sedangkan terdapat 70 kali aktivitas perusahaan dengan kategori tidak menggunakan hedging dan persentase sebesar 43,8 \%.

Uji kelayakan model regresi dapat dinilai dengan melihat tabel Hosmer and Lemeshow Test pada SPSS. Tabel Hosmer and Lemeshow Test menguji hipotesis nol bahwa data empiris cocok atau sesuai dengan model. Hasil uji kelayakan model dapat dilihat pada Tabel Hosmer and lemeshow Test pada Tabel 3. sebagai berikut:

Tabel 3.

Hosmer and Lemeshow Test

\begin{tabular}{cccc}
\hline Step & Chi-square & Df & Sig. \\
\hline 1 & 6.353 & 8 & .608 \\
\hline Sumber: & & &
\end{tabular}

Model regresi pada penelitian ini menunjukkan nilai statistik Hosmer and Lemeshow Test sebesar 6,353 dengan probabilitas signifikansi sebesar 0,608. Nilai siginifikansi menunjukkan angka sebesar 0,608 hal ini berarti bahwa model didalam penelitian ini dapat diterima karena cocok dengan data observasinya dan dapat menjelaskan pengaruh variabel bebas dan variabel terikatnya.

Penilaian keseluruhan model dapat di nilai dengan membandingkan nilai antara -2 Log Likehood pada awal (block number $=0$ ) dengan nilai -2 Log Likehood pada akhir (block number $=1$ ). Model -2 Log Likehood dikatakan dapat menunjukan data model regresi yang baik apabila nilai dari -2 Log Likehood (block number $=0$ ) $>$ nilai -2 Log Likehood (block number=1). Hasil penilaian keseluruhan model dapat pada Tabel 4 Iteration Histor $y^{\mathrm{a}, \mathrm{b}, \mathrm{c}}$ sebagai berikut:

Tabel 4.

Iteration History ${ }^{\text {a.b.c }}$ Block Number $=0$

\begin{tabular}{|c|c|c|c|}
\hline \multicolumn{2}{|c|}{ Iteration } & -2 Log likelihood & $\begin{array}{c}\text { Coefficients } \\
\text { Constant }\end{array}$ \\
\hline \multirow[t]{3}{*}{ Step 0} & 1 & 219.301 & .250 \\
\hline & 2 & 219.301 & .251 \\
\hline & 3 & 219.301 & .251 \\
\hline
\end{tabular}

Sumber: Data diolah, 2019

Tabel 5.

Iteration History ${ }^{\mathrm{a}, \mathrm{b}, \mathrm{c}}$ Block Number $=1$

\begin{tabular}{ccccccc}
\hline \multirow{2}{*}{ Iteration } & & -2 Log likelihood & Constant & Z-Score & MBVE & CR \\
\hline \multirow{2}{*}{ Step 1 } & 1 & 197.973 & .726 & .120 & .202 & -.006 \\
& 2 & 196.811 & .804 & .145 & .295 & -.007 \\
& 3 & 196.782 & .801 & .144 & .317 & -.007 \\
& 4 & 196.782 & .801 & .144 & .318 & -.007 \\
\hline
\end{tabular}

Sumber: Data diolah, 2019

Pada Tabel 4. dan Tabel 5. yang digunakan untuk menilai keseluruhan model dapat dilakukan dengan membandingkan nilai -2 Log Likehood (block number $=0$ ) dengan -2 Log Likehood (block number=1). Nilai pada -2 Log Likehood (block number $=0$ ) adalah sebesar 219,301 dan setelah dimasukkan tiga variabel bebas nilai -2 Log Likehood pada akhir mengalami penurunan menjadi 196,782. Penurunan yang terjadi pada nilai -2 Log Likehood menunjukkan model regresi yang baik atau dengan kata lain model yang dihipotesiskan cocok dengan data. 
Model regresi yang baik adalah dengan tidak adanya gejala korelasi yang kuat antara variabel bebasnya. Pengujian multikolinearitas dalam regresi logistik menggunakan matrik untuk melihat besarnya korelasi antara variabel bebas. Matrik korelasi dikatakan tidak memiliki gejala multikolinearitas yang serius apabila nilai matrik korelasi lebih kecil dari 0,8. Tabel 6. menunjukkan matriks korelasi antar variabel bebas.

Tabel 6.

Correlation Matrix

\begin{tabular}{lccccc}
\hline & & Constant & Z-Score & MBVE & CR \\
\hline Step 1 & Constant & 1.000 & .397 & -.439 & -.772 \\
& Z-Score & .397 & 1.000 & -.409 & -.678 \\
& MBVE & -.439 & -.409 & 1.000 & .170 \\
& CR & -.772 & -.678 & .170 & 1.000 \\
\hline
\end{tabular}

Sumber: Data diolah, 2019

Hasil Tabel 6. menunjukkan tidak terdapat nilai koefisien antar variabel yang nilainya lebih besar dari 0,8 sehingga dapat disimpulkan bahwa tidak terdapat gejala multikolinearitas yang serius antar variabel.

Matriks klasifikasi menunjukkan kekuatan prediksi dari model regresi untuk memprediksi probabilitas aktivitas hedging pada suatu perusahaan. Kekuatan prediksi dari model regresi untuk memprediksi kemungkinan terjadinya variabel terikat dinyatakan dalam bentuk persentase. Hasil Tabel kualifikasi ditampilkan pada Tabel 7.

Tabel 7.

Classification Table ${ }^{\mathrm{a}}$

\begin{tabular}{|c|c|c|c|c|}
\hline & & \multicolumn{3}{|c|}{ Predicted } \\
\hline \multirow{2}{*}{\multicolumn{2}{|c|}{ Observed }} & & & \\
\hline & & $\mathbf{0}$ & 1 & Percentage Correct \\
\hline \multirow[t]{2}{*}{ hedge } & 0 & 36 & 34 & 51.4 \\
\hline & & 19 & 71 & 78.9 \\
\hline \multicolumn{2}{|c|}{ Overall Percentage } & & & 66.9 \\
\hline
\end{tabular}

Sumber: Data diolah, 2019

Pada Tabel 7. menunjukkan kekuatan prediksi dari model regresi untuk memprediksi perusahaan melakukan hedging adalah sebesar 78,9 \%. Hal ini menunjukkan bahwa dengan menggunakan model regresi tersebut, terdapat sebanyak 71 observasi yang diprediksi akan melakukan hedging dari total 90 observasi yang melakukan hedging. Kekuatan prediksi dari model regresi untuk memprediksi kemungkinan perusahaan tidak melakukan hedging adalah 51,4\%. Model tersebut menunjukkan terdapat sebanyak 36 observasi yang tidak melakukan hedging dari total 70 observasi yang tidak melakukan hedging. Secara keseluruhan ketepatan klasifikasi pada model ini adalah $66,9 \%$, yang berarti hasil penelitian ini cukup baik karena mendekati $100 \%$.

Kuatnya variabel bebas terhadap variabel terikat dapat dilihat dari nilai Nagelkerke $R$ Square. Nilai dari Nagelkerke $R$ Square dapat menjelaskan sejauh mana kemampuan model dalam menerangkan variasi total dari variabel terikat yang mampu dijelaskan oleh variabel bebas. Tabel 8. menunjukkan nilai Nagelkerke $R$ 
Square sebesar 0,176. Nilai tersebut berarti bahwa variasi dari variabel Z-Score, MBVE dan CR (variabel bebas) mampu menjelaskan variasi dari hedging (variabel terikat) sebesar $17,6 \%$ sedangkan $82,4 \%$ dijelaskan oleh variasi variabel lain yang tidak dimasukkan dalam model persamaan regresi.

Tabel 8.

Model Summary

\begin{tabular}{cccc}
\hline Step & $\mathbf{- 2}$ Log likelihood & Cox \& Snell R Square & Nagelkerke R Square \\
\hline 1 & $196.782^{\mathrm{a}}$ & .131 & .176 \\
\hline
\end{tabular}

Sumber: Data diolah, 2019

Model regresi logistik dapat dibentuk dengan cara melihat pada nilai estimasi parameter dalam Variable in The Equation. Model regresi logistik yang terbentuk berdasarkan nilai estimasi parameter dalam Variable in The Equation ditampilkan pada Tabel 8 .

Tabel 9.

Variables in the Equation

\begin{tabular}{rlrrrrrr}
\hline & & B & S.E. & Wald & df & \multicolumn{1}{c}{ Sig. } & \multicolumn{1}{c}{$\operatorname{Exp(B)}$} \\
\hline Step $1^{\text {a }}$ & Z-Score & -.144 & .107 & 1.827 & 1 & .176 & 1.155 \\
& MBVE & .318 & .160 & 3.968 & 1 & .046 & 1.375 \\
& CR & -.007 & .002 & 9.422 & 1 & .002 & .993 \\
& Constant & .801 & .382 & 4.398 & 1 & .036 & 2.228 \\
\hline
\end{tabular}

Sumber: Data diolah, 2019

Model regresi yang terbentuk berdasarkan nilai estimasi parameter dalam Variable in The Equation adalah sebagai berikut:

$$
\text { Ln } \frac{p}{1-p}=0,801-0,144 \mathrm{ZScore}+0,318 \mathrm{MBVE}-0,007 \mathrm{CR}
$$

Variabel z-score yang merupakan proksi dari financial distress menunjukkan nilai koefisien regresi sebesar -0,144 dengan pergerakan nilai probabilitas variabel sebesar 0,176 yang lebih besar dari tingkat signifikansi 0,05 (5\%). Hal ini mengandung arti bahwa $\mathrm{H}_{1}$ diterima, dan menunjukkan bahwa variabel z-score memiliki pengaruh yang negatif tidak signifikan terhadap keputusan hedging perusahaan sektor pertambangan yang terdaftar di Bursa Efek Indonesia.

Variabel MBVE yang merupakan proksi dari growth opportunities menunjukkan nilai koefisien regresi sebesar 0,318 dengan pergerakan nilai probabilitas variabel sebesar 0,046 yang lebih kecil dari tingkat signifikansi 0,05 (5\%). Hal ini mengandung arti bahwa $\mathrm{H}_{2}$ diterima, dan menunjukkan bahwa variabel MBVE memiliki pengaruh yang positif signifikan terhadap keputusan hedging perusahaan sektor pertambangan yang terdaftar di Bursa Efek Indonesia.

Variabel CR yang merupakan proksi dari liquidity menunjukkan nilai koefisien regresi sebesar $-0,007$ dengan pergerakan nilai probabilitas variabel sebesar 0,002 yang lebih kecil dari tingkat signifikansi 0,05 (5\%). Hal ini mengandung arti bahwa $\mathrm{H}_{3}$ diterima, dan menunjukkan bahwa variabel $\mathrm{CR}$ memiliki pengaruh yang negatif signifikan terhadap keputusan hedging perusahaan sektor pertambangan yang terdaftar di Bursa Efek Indonesia. 
Penelitian ini bertujuan untuk menguji pengaruh financial distress, growth opportunities, dan liquidity terhadap keputusan hedging pada perusahaan pertambangan periode 2014 - 2018. Pada penelitian ini financial distress diproksikan dengan z-score, growth opportunities diproksikan dengan market to book value of equity dan liquidity diproksikan dengan current ratio.

Hasil uji regresi logistik menemukan hasil bahwa z-score yang merupakan proksi dari financial distress memiliki pengaruh negatif dan tidak signifikan secara statistik terhadap variabel terikat yaitu keputusan hedging dengan menggunakan instrumen derivatif. Hasil menunjukkan bahwa hipotesis satu yang menyebutkan bahwa financial distress berpengaruh negatif dan tidak signifikan terhadap keputusan hedging dapat diterima.

Hasil pengujian ini sesuai dengan temuan dari penelitian Wulandari (2018), Nuzul dan Lautania (2015) dan Yustika (2015) menemukan hasil bahwa financial distress yang diukur dengan menggunakan z-score berpengaruh negatif dan tidak signifikan terhadap keputusan hedging pada perusahaan sektor pertambangan di Indonesia.

Hasil penelitian yang bernilai negatif dan tidak signifikan menunjukkan bahwa semakin kecil nilai z-score maka semakin banyak perusahaan yang melakukan hedging, karena perusahaan tersebut berada pada kategori potensial bangkrut sehingga akan lebih berhati - hati dalam mengelola keuangannya. Perusahaan akan terdorong untuk melindungi diri dari berbagai risiko termasuk risiko fluktuasi nilai tukar mata uang ketika nilai z-score menurun. Hutang dan piutang dalam mata uang asing dapat memperburuk keadaan keuangan perusahaan jika tidak dilakukan hedging dengan menggunakan instrumen derivatif.

Hasil uji regresi logistik menemukan bahwa market to book of equity yang merupakan proksi dari growth opportunities memiliki pengaruh positif dan signifikan secara statistik terhadap variabel terikat yaitu keputusan hedging dengan menggunakan instrumen derivatif. Hasil menunjukkan bahwa hipotesis dua yang menyebutkan bahwa growth opportunities berpengaruh positif dan signifikan terhadap keputusan hedging dapat diterima.

Hasil pengujian ini sesuai dengan penelitian yang dilakukan oleh Sharagih (2017), Gustira (2018), Maria \& Mahfudz (2016) serta Utami (2018) yang melakukan penelitian tentang growth opportunities dan menemukan hasil bahwa growth opportunities berpengaruh positif dan signifikan terhadap keputusan hegding.

Hasil penelitian menunjukkan nilai positif dan signifikan hal ini berarti bahwa perusahaan yang memiliki peluang pertumbuhan yang tinggi akan membutuhkan tambahan modal dari pihak luar atau eksternal untuk membiayai kegiatan operasional yang akan dilakukan perusahaan. Dana eksternal yang dibutuhkan tersebut dapat diperoleh dari luar maupun dalam negeri, ketika memperoleh dari luar negeri maka akan menghadapi risiko fluktuasi nilai tukar. Ketika mata uang lokal terdepresiasi maka perusahaan akan mengalami kerugian, sehingga untuk meminimalisir risiko tersebut perusahaan akan membutuhkan hedging.

Hasil uji regresi logistik menemukan bahwa current ratio yang merupakan proksi dari liquidity memiliki pengaruh negatif dan signifikan secara statistik terhadap variabel terikat yaitu keputusan hedging dengan menggunakan instrumen 
derivatif. Hasil menunjukkan bahwa hipotesis tiga yang menyebutkan bahwa liquidity berpengaruh negatif dan signifikan terhadap keputusan hedging dapat diterima.

Hasil pengujian ini sesuai dengan penelitian yang dilakukan oleh Megawati (2016), Dewi \& Purnawati (2016) serta Aslikan \& Rokhmi (2017) yang melakukan penelitian tentang liquidity dan menemukan hasil bahwa liquidity berpengaruh negatif dan signifikan terhadap keputusan hedging.

Hasil penelitian menunjukkan nilai negatif dan signifikan hal ini berarti bahwa semakin liquid perusahaan maka perusahaan tersebut akan terhindar dari risiko, oleh karena itu kemungkinan perusahaan menerapkan hedging akan semakin rendah. perusahaan yang liquid memiliki cadangan dana yang cukup untuk menghadapi risiko - risiko yang mungkin terjadi sehingga tidak membutuhkan hedging. Current ratio yang rendah menunjukkan ketidakmampuan perusahaan memenuhi kewajiban jangka pendeknya maupun membiayai kegiatan operasinya sehingga risiko kegagalan yang dihadapi semakin tinggi, oleh karena itu perusahaan perlu melakukan hedging untuk mengelola risikonya.

Variabel z-score, MBVE, dan current ratio dapat menunjukkan penurunan kondisi keuangan perusahaan, ukuran peluang perusahaan dan kemampuan perusahaan untuk dapat memenuhi kewajiban finansialnya dalam jangka pendek. Suatu perusahaan akan terdorong untuk melindungi diri dari berbagai risiko termasuk risiko fluktuasi nilai tukar mata uang ketika perusahaan tersebut berada pada posisi potensial bangkrut. Hutang dan piutang dalam mata uang asing dapat memperburuk keadaan keuangan perusahaan jika tidak dilakukan hedging. Suatu perusahaan jika memilki ukuran peluang perusahaan yang besar maka mengindikasikan bahwa perusahaan tersebut akan membutuhkan tambahan modal dari pihak luar atau eksternal untuk membiayai kegiatan operasional yang akan dilakukan perusahaan. Dana eksternal yang dibutuhkan tersebut dapat diperoleh dari luar maupun dalam negeri, ketika memperoleh dari luar negeri maka akan menghadapi risiko fluktuasi nilai tukar. Perusahaan akan mengalami kerugian apabila mata uang lokal terdepresiasi, sehingga untuk meminimalisir risiko tersebut perusahaan akan membutuhkan hedging. Suatu perusahaan apabila memiliki kemampuan untuk dapat memenuhi kewajiban finansialnya dalam jangka pendek maka mengindikasikan bahwa perusahaan tersebut akan terhindar dari risiko, oleh karena itu kemungkinan perusahaan menerapkan hedging akan semakin rendah. Perusahaan yang mampu memenuhi kewajiban jangka pendeknya memiliki cadangan dana yang cukup untuk menghadapi risiko - risiko yang mungkin terjadi sehingga tidak membutuhkan hedging.

Berdasarkan penelitian yang telah dilakukan dapat diketahui bahwa secara teoritis, penelitian ini mendukung beberapa teori yang telah ada pada sebelumnya. Penelitian mengenai pengaruh financial distress, growth opportunities, dan liquidity terhadap keputusan hedging diharapkan menjadi suatu bukti baru dengan hasil yang berbeda dari hipotesis ini untuk manajemen keuangan internasional. Pengolahan data dilakukan dengan menggunakan regresi logistik dengan berbagai uji yang digunakan untuk memperkirakan hubungan antar variabel - variabel yang telah ditetapkan sebelumnya berdasarkan teori. Hasil penelitian ini diharapkan dapat digunakan untuk memperkaya referensi yang berkaitan dengan financial 
distress, growth opportunities dan liquidity serta keputusan hedging. Hasil penelitian ini diharapkan dapat dijadikan masukan bagi perusahaan yang melakukan transaksi internasional agar nantinya dapat mengurangi risiko yang timbul dari adanya eksposur fluktuasi kurs valuta asing.

\section{SIMPULAN}

Hasil penelitian menunjukan bahwa financial distress memiliki pengaruh negatif dan tidak signifikan terhadap keputusan hedging dengan menggunakan instrumen derivatif. Hasil penelitian menunjukkan bahwa growth opportunities memiliki pengaruh positif dan signifikan terhadap keputusan hedging dengan menggunakan instrumen derivatif. Hasil penelitian menunjukkan bahwa liquidity memiliki pengaruh negatif dan signifikan terhadap keputusan hedging dengan menggunakan instrumen derivatif.

Bagi perusahaan pertambangan khususnya yang melakukan transaksi internasional yang menghadapi ketidakpastian akibat dari fluktuasi valuta asing sebaiknya menggunakan hedging ketika kondisi perekonomian tertentu untuk melindungi perusahaan. Bagi investor yang ingin melakukan investasi pada perusahaan pertambangan perlu memperhatikan variabel growth opportunities karena variabel tersebut berpengaruh terhadap keputusan hedging sehingga dapat diketahui bagaimana kemampuan perusahaan dalam mengelola risiko yang sedang dan akan dihadapi. Peneliti selanjutnya disarankan dapat meneliti lebih lanjut mengenai faktor - faktor yang mempengaruhi keputusan hedging selaian dari variabel dalam penelitian ini seperti leverage, kebijakan deviden, profitabilitas, dan proporsi komisaris dengan menggunakan sektor yang berbeda seperti sektor food and beverage, otomotif, dan manufaktur.

\section{REFERENSI}

Altuntas, M., Lienberg, A. P., Watson, E. D., \& Yildiz, S. (2017). Hedging, Cash Flows and Firm Value: Evidence of an Indirect Effect. Journal of Insurance Issues, 40(1), 1-22.

Ariani, N. N. N., \& S. G. M. (2017). Pengaruh Leverage, Profitabilitas, Dan Likuiditas Terhadap Keputusan Hedging Perusahaan Sektor Pertambangan Di Bursa Efek Indonesia. E-Jurnal Manajemen Universitas Udayana, 6(1), 347-374.

Arnold, M. M., Rathgeber, A. W., \& Stockl, S. (2014). Determinants of Corporate Hedging: A (Statistical) Meta-Analysis. The Quarterly Review of Economics and Finance, 54, 443-458.

Aslikan, I., \& Rokhmi, S. (2017). Faktor - faktor yang Mempengaruhi Keputusan Hedging pada Perusahaan Manufaktur. Jurnal Ilmu Dan Penelitian Manajemen, 6(5), 1-20.

Brigham, E. F., \& Joel, F. H. (2018). Dasar-dasar Manajemen Keuangan (Edisi Empat Belas). Salemba Empat. 
Candradewi, M. R., \& Rahyuda, H. (2018). Variabel -Variabel Penentu Pengguna Derivatif Perusahaan Non- Keuangan Di Bursa Efek Indonesia. Matrik: Jurnal Manajemen, Strategi Bisnis Dan Kewirausahaan, 12(1), 1-14.

Chaudry, N. I., Mehmood, M. S., \& Mehmood, A. (2014). Dynamics of Derivatives Usage and Firm Value. Wulfenia Journal, 21(6), 122-140.

Chong, L. L., Chang, J. X., Tan, S., \& H. (2014). The Determinants of Foreign Currency Risk Hedging. Journal of Management Finance, 40(2), 176-187.

Dewi, K. R. U., \& Purnawati, K. (2016). Pengaruh Market to Book Value dan Likuiditas Terhadap Keputusan Hedging Pada Perusahaan Manufaktur di Bursa Efek Indonesia. E-Jurnal Manajemen Universitas Udayana, 5(1), 355384.

Dewi, M. P., \& I. S. (2018). Analisis Ekspor Batu Bara Indonesia. Jurnal Akuntansi Dan Audit Indonesia, 22(1), 1-19.

Fatimia, A., Sulhan, M. (2016). Pengaruh leverage, financial distress dan liquidity sebagai pengambilan keputusan hedging. Iqtishoduna: Jurnal Ekonomi Dan Bisnis Islam, 12(2), 64-72.

Guniarti, F. (2014). Faktor-Faktor yang Mempengaruhi Aktivitas Hedging dengan Instrumen Derivatif Valuta Asing. Jurnal Dinamika Manajemen, 5(1), 6479.

Gustira, R., Rambe, P. A., \& Adel, J. F. (2018). Pengaruh Leverage, Likuiditas, Growth Opportunity, Financial Distress dan Cash Flow Volatility Terhadap Keputusan Hedging Menggunakan Instrumen Derivatif Pada Perusahaan Sektor Aneka Industri yang Terdaftar di BEI Periode 2013-2016. Jurnal Akuntansi: Fakultas Ekonomi Universitas Maritim Raja Ali Haji, 1-20.

Hanafi, M. M. (2015). Manajemen Risiko. Yogyakarta: Sekolah Tinggi Ilmu Manajemen YKPN.

Irawan, B. P. (2014). Analisis Faktor yang Mempengaruhi Aktivitas Instrumen Derivatif Valuta Asing Sebagai Pengambilan Keputusan Hedging. Diponogoro Journal of Management, 8(1), 1-17.

Jiwandhana, R. S. P., \& Triaryati, N. (2016). Pengaruh Leverage Dan Profitabilitas Terhadap Keputusan Hedging Perusahaan Manufaktur Indonesia. E-Jurnal Manajemen Universitas Udayana, 5(1), 31-58.

Krisdian, N. P. C., \& Badjra, I. B. (2017). Pengaruh Ukuran Perusahaan, Tingkat Hutang, Dan Kesulitan Keuangan Terhadap Keputusan Hedging Pada Perusahaan Manufaktur Indonesia. E-Jurnal Manajemen Universitas Udayana, 6(3), 1452-1477.

Maria, J. W. A., \& M. (2016). Analisis Fakor-Faktor yang Memengaruhi Keputusan Hedging dengan Derivatif Valuta Asing (Studi Pada Perusahaan NonFinansial yang Terdaftar di Bursa Efek Indonesia Periode Tahun 2011-2014). 
Institutional Repository: Diponegoro University, 5(3), 1-14.

Medina, I. (2016). Analisis Faktor- Faktor Yang Mempengaruhi Pengambilan Keputusan Lindung Nilai (Hedging) Menggunakan Instrumen Derivatif. Diponegoro Journal Of Management, 5(2), 1-14.

Megawati, I. A. P., \& Wiagustini, N. L. P. (2016). Determinasi Keputusan Hedging Pada Perusahaan Manufaktur di Bursa Efek Indonesia. E- Jurnal Ekonomi Dan Bisnis Universitas Udayana, 5(10), 3391-3418.

Mehmood, A. (2014). Determinants of Corporate Hedging Policies and Derivatives Usage in Risk Management Practices of Non-Financial Firms. Wulfenia Journal, 21(7), 293-310.

Nuzul, H., \& Lautania, M. F. (2015). Pengaruh Leverage, Financial Distress, dan Growth Options Terhadap Aktivitas Hedging Pada Perusahaan NonKeuangan yang Terdaftar di Bursa Efek Indonesia. Jurnal Dinamika Akuntansi Dan Bisnis, 2(2), 104-113.

Platt, H., \& Platt, M. B. (2014). Predicting Financial Distress. Journal of Financial Service Professionals, 56(3), 12-15.

Raghavendra, R. H., \& Velmurugan, P. S. (2014). The Determinants of Currency Hedging in Indian IT Firms. Journal of Business and Financial Affairs, 3(3), $1-7$.

Rinaldi M., Jamal, A., \& Seftarita, C. (2017). Analisis Pengaruh Perdagangan Internasional Dan Variabel Makro Ekonomi Terhadap Pertumbuhan Ekonomi Indonesia. Jurnal Ekonomi Dan Kebijakan Publik, 4(1), 25498355.

Ross, S., Westerfield, R., \& Jaffe, J. (2019). Corporate Finance (10th Edition).

Saraswati, A. P., \& Suryantini, N. P. S. (2019). Pengaruh Leverage, Firm Size, Profitabilitas Terhadap Keputusan Hedging Pada Perusahaan Manufaktur di Bursa Efek Indonesia. E-Jurnal Manajemen Universitas Udayana, 8(5), 2999-3027.

Sartono, A. (2014). Manajemen Keuangan Teori dan Aplikasi (Edisi Empat).

Sharagih, F., \& M. (2017). Pengaruh Growth Opportunity, Firm Size, Dan Liquidity Terhadap Keputusan Hedging Pada Perusahaan Perbankan Indonesia. Jurnal Ilmu Manajemen-Jurusan Manajemen Fakultas Ekonomi Universitas Negeri Surabaya, 2(2), 1-10.

Sianturi, C. N., \& Pangestuti, I. R. D. (2015). Pengaruh Liquidity, Firm Size, Growth Opportunity, Financial Distress, Leverage dan Managerial Ownership Terhadap Aktivitas Hedging dengan Instrumen Derivatif. Diponegoro Journal Of Management, 4(4), 1-13.

Situmeang, Y. M. L., \& Wiagustini, N. L. P. (2018). Pengaruh Struktur Modal Terhadap Nilai Perusahaan dengan Kebijakan Hedging Sebagai Mediasi Pada 
Perusahaan BUMN Go-Public. E-Jurnal Manajemen Unud, 7(3), 1368-1396.

Tuzcu, S. E. (2015). The Effect of Derivatives Activity on Bank Profitability Before and During the Subprime Mortgage Crisis: Evidence from Turkey. Ankara Universitesi Sosyal Bilimler, 6(1), 29-56.

Utami, V. J., Artati, S., \& Putriana, M. (2018). Pengaruh Corporate Social Responsibility Terhadap Manajemen Laba dengan Leverage dan Growth Sebagai Variabel Control Pada Industri Farmasi yang Terdaftar di Bursa Efek Indonesia. Jurnal Manajemen Dan Sains, 3(2), 226-236.

Weston, J. F., \& Brigham, E. F. (2018). Dasar-dasar Manajemen Keuangan (14thed).

Wiagustini, N. L. P. (2014). Dasar-Dasar Manajemen Keuangan.

Widyagoca, I. G. P. A., \& Lestari, P. V. (2016). Pengaruh Leverage, Growth Opportunities, Dan Liquidity Terhadap Pengambilan Keputusan Hedging PT. Indosat Tbk. E-Journal Manajemen Universitas Udayana, 5(2), 1282-1308.

Wulandari, I., Nugraeni., \& Wafa, Z. (2018). Faktor-Faktor yang Mempengaruhi Financial Distress Pemerintah Daerah. JRMAB Prodi Akuntansi, 4(2), 100105.

Yustika, Y. (2015). Pengaruh Likuiditas, Leverage, Profitabilitas, Operating Capacity dan Biaya Agensi Manajerial Terhadap Financial Distress. Jom FEKON, 2(2), 1-15.

Zeinora. (2016). Hedging, Future Contract dengan Swap Contract untuk Meminimalisasi Risiko Fluktuasi Kurs Valas. Journal of Applied Business and Economics, 3(1), 10-18. 